\title{
Dormitory-Based Intervention Method for Children with Special Needs
}

\author{
Darmin Tuwu, ${ }^{1}$ Bahtiar, ${ }^{2}$ \\ Muhammad Arsyad, ${ }^{3}$ Suharty \\ Roslan 4 \\ 1,2,3,4Universitas Halu Oleo Kendari- \\ Indonesia
}

Corresponding Author: Darmin Tuwu, email: darmintuwu@gmail.com; Kampus Hijau Bumi Tridharma Anduonou Kendari, 93132

\begin{abstract}
The article aims to elaborate the micro intervention method on fifty problem children guided in Social Institutions for children and adolescents of Social Office in Southeast Sulawesi Province. This qualitative descriptive study focuses on the study of problem children: mocking one another, skipping school, going out of the night without getting permission from the childminder, not following to do the prayer together, and liking to tell a lie. Methods of data-collecting are observation and interview. This study showed that dormitory-based micro intervention methods for problem children use mental-spiritual guiding, physical guiding and extracurricular activity. The findings are as follows: 1) specifically for the children who mock their friends, they will be cultivated by way of advising and making them aware of resisting the deed of mocking because the conduct is a terrible deed, violating the ethics, and not to be in line with the religious and cultural norms; 2) for the children who do not follow to do the prayer together, to go out of night without getting permission from the boarder, skipping school, will be cultivated physically so that the children stop his bad habit and change it with a positive habit, such as: studying in, reading the Quran, doing sport, and sharing the other positive activities at night; and 3) there must be the supporting and collaboration with various stakeholders like a university, business world, society, and Non-Governmental Organization to realize the implementation of integrated child protection and to create social welfare of the children in the future.
\end{abstract}

Keywords: micro intervention methods; children with special needs; dormitory-based rehabilitation

Abstrak: Artikel ini bertujuan untuk mengelaborasi metode intervensi mikro pada lima puluh anak binaan di Panti Sosial Anak dan Remaja Dinas Sosial Provinsi Sulawesi Tenggara. Penelitian deskriptif kualitatif ini menitikberatkan pada kajian anak bermasalah seperti: saling mengejek, bolos sekolah, keluar malam tanpa izin dari pengasuh anak, tidak mengikuti sholat berjamaah, dan suka berdusta. Metode pengumpulan data adalah observasi dan wawancara. Hasil penelitian menunjukkan bahwa metode intervensi mikro berbasis asrama pada anak bermasalah menggunakan pembinaan mental-spiritual, pembinaan fisik, dan kegiatan ekstrakurikuler. Adapun temuannya adalah sebagai berikut: 1) khusus bagi anak-anak yang mengejek temannya akan dibina dengan cara menasihati dan menyadarkannya untuk menolak perbuatan mengejek 


\begin{abstract}
karena perbuatan tersebut adalah perbuatan yang tidak baik, melanggar etika, dan tidak sejalan dengan norma agama dan budaya; 2) bagi anak-anak yang tidak ikut salat berjamaah, keluar malam dari asrama tanpa izin, membolos sekolah, dibina secara fisik agar anak menghentikan kebiasaan buruknya dan mengubahnya dengan kebiasaan yang positif, seperti: belajar, membaca al-Qur'an, berolahraga, dan berbagi aktivitas positif lainnya di malam hari; dan 3) harus ada dukungan dan kerjasama dengan berbagai pemangku kepentingan seperti perguruan tinggi, dunia usaha, masyarakat, dan Lembaga Swadaya Masyarakat untuk mewujudkan penyelenggaraan perlindungan anak yang terintegrasi dan mewujudkan kesejahteraan sosial anak di masa depan.
\end{abstract}

Kata Kunci: metode intervensi mikro; anak dengan kebutuhan khusus; rehabilitasi berbasis asrama

\title{
A. Introduction
}

This writing concerns the method of managing the problem children in Social Institution for children and adolescent. Article 1 on item 1 (The Child Protection Laws No 23, 2002) ${ }^{1}$ that: "child is someone who has not yet been at the age of 18 years, including the one who is still in the fetus." The child denotes a love product that should get affection and protection from their parents and their adults in its surroundings. Childhood is filled with playing, having fun with friends. However, in reality, not all children enjoy happy times in their life due to family conditions. The child who lives in parental care is different from living in another person's care. The situation, in turn, affects the psychological development and characteristics of the child.

Parents should understand the child's characteristics to be educated, cultivated, and guided in line with their unique condition. Some of the children characteristics are: moving a lot, liking to imitate, liking to oppose, asking the questions a lot, having sharp and automatical memory, liking spirit and motivation, liking to play and have fun, liking to compete, indulging in infancies, having fast language development, having the sharp feeling, being labile, and being easy to be involved in problems. Therefore, the children require aid, guidance, and protection from the adults (parents, educators, and other parties) to live independently and are free from the problems. It is in keeping with the purpose of social welfare, namely fulfilling social needs, finance, health,

\footnotetext{
1Undang-Undang No. 23/2002 tentang Perlindungan Anak.
} 
education, and recreation required by all individuals (including the child) in the society. $^{2}$

The psychological condition of children still labile tends to make them easily influenced by the social environment where they live even they are susceptible to problems. Many problems frequently occur on children: violence on children, child delinquency, adolescent brawl, sexual harassment, discrimination, exploitation of children, the neglect of children, and injustice, and so forth. By seeing many problems that can occur in children, there needs to be an effort to manage, cultivate, and social intervention children's social functioning. ${ }^{3}$ Social functioning refers to individuals and collectivities in carrying out their life tasks and fulfilling their life. ${ }^{4}$ Accordingly, children's social functioning is a condition that refers to the re-functioning of a child socially after undergoing the problems that occur on them through the external intervention party (parents, educators, and other parties) to do his social role as a child.

One of the institutions that focus on cultivating children is the Regional Technical Implementation Unit (RTIU) of the Social Institution of the Children and Adolescent (SICA) of the Social Office of Southeast Sulawesi Province. RTIUSICA of Social Office of Southeast Sulawesi Province as the instance of local government that moves in the humanitarian, social field is active to give the cultivation activity and material and non-material aid to the children. Since the New Order, RTIU-SICA has managed children's problems, even the handling and rehabilitation given to the children and the babies at the age of under five years, adolescents, and the elderly.

The children recruited in SICA come from all regencies/cities in Southeast Sulawesi, with various backgrounds of the children's family, namely the orphanage, the poor, and the broken. The period of recruitment of the children occurs in the whole year that begins from January to December. While they live in a dormitory, the children will be cultivated and sent to school until they graduate from Senior High School.

\footnotetext{
${ }^{2}$ Charles Zastrow, Empowerment Series: Introduction to Social Work and Social Welfare: Empowering People (Boston, MA: Cengage Learning, 2016).

${ }^{3}$ Adi Fahrudin, Perspektif Biopsikososial Untuk Asesmen Keberfungsian Sosial (Bandung: Refika Aditama, 2018).

${ }^{4}$ M Siporin, Introduction to Social Work Practice (New York: MacMillan, 1975).
} 
In 2020, RTIU of Social Institution for children and adolescents in Kendari guided 50 children. ${ }^{5}$ During in the dormitory, the children live in a cottage. Every room is resided by two up to 3 kids with 1 boarding father. While they live in the dormitory, they are handled by an orphanage builder. The children obtain the service in the form of counseling, education, and facility of infrastructures freely. For the children's education, the dormitory handler has collaborated with the nearest schools like Senior High Schools of Ilmiah Kendari, Senior High School XI Kendari, and Junior High School XI Kendari. The children obtain the facility in school uniform and equipment, sleeping-tools, bathing-equipment, consumption, and transportation fee for the needs.

In cultivating children in the dormitory, various obstacles and problems are found, both from the dormitory handler and the ones coming from the children. The problems coming from the dormitory is the lack of infrastructures and human resources. They are competent in social welfare and social work sciences so that it gives the impact on less maximal teaching and cultivating process done by the dormitory handler party towards the children and adolescent that finally will affect the quality and achievement of teaching and cultivating towards children in dormitory handler in totality.

The problems coming from the children who have lived in dormitory handlers are the indiscipline ones, bothering and bullying one another, skipping school, going out of the night without getting permission from the dormitory handler, not following to do prayer together, and telling a lie.

In the pandemic of COVID-19 era, the children who live in dormitory are getting bored and getting stress. ${ }^{6}$ The problems of this child must soon be handled; otherwise, it can be a severe problem. In the perspective of Wong, the problem children's condition is mental illness. ${ }^{7}$ Considering that there many problems faced by the children in dormitory, they need to be interfered with micro intervention method through counseling method ${ }^{8}$ and therapy as the

\footnotetext{
${ }^{5}$ Hanani Firdhotul Jannah, Bahtiar Bahtiar, and Sarpin Sarpin, "Program Pemberdayaan Anak Kurang Mampu pada Panti Sosial (Studi di UPTD Panti Sosial Anak dan Remaja Dinas Sosial Provinsi Sulawesi Tenggara)," Welvaart: Jurnal Ilmu Kesejahteraan Sosial 1, no. 2 (2020): 132-45.

${ }^{6}$ Darmin Tuwu et al., "Pemberian Dukungan Psikososial pada Anak yang Mengalami Gangguan di Era Pandemi COVID-19," Journal Publicuho 3, no. 3 (2020): 394-404, https://doi.org/ 10.35817/jpu.v3i3.14489.

${ }^{7}$ Daniel Fu Keung Wong, Clinical Case Management for People with Mental Illness: A Biopsychosocial Vulnerability-Stress Model (London: Routledge, 2006).

8 Jeanette Murad Lesmana, Dasar-Dasar Konseling (Jakarta: UI Press, 2011).
} 
solution of the problems faced by the children so that they can function socially and independently. ${ }^{9}$

Based on the above explanations, this writer wants to elaborate on the problems that frequently occur in the children, social services are given to the children, and what method of handling is proper to be given to overcome the child's problems, so that the child can function socially.

\section{B. Problems on Children}

The children are social creatures who have not yet been matured in the light of physical growth and psychological development that still require the care, love, affection, attention, and education to support their development. Childhood is marked by the physical, social, and mental-psychological development with the body condition that keeps changing so that it often appears various problems in the children's self. Any problem that befalls the children will influence the physical growth and psychological development both directly and indirectly.

Many problems frequently befall the children, either the children as the actor or the victims, beginning from the economy, religion, social, psychology, culture, politics, education, health, and violence. ${ }^{10}$ For example, the problem of the children like the problems related to physical, psychological, and social conditions, and learning-difficulty, ${ }^{11}$ sexual harassment, ${ }^{12}$ or destructive conduct from the children and adolescent, such as the brawl, liquor, free sex deed, theft, raping, and robbery, ${ }^{13}$ the children as the victim of the violent act, ${ }^{14}$

\footnotetext{
${ }^{9}$ Matthew D. Selekman, Solution-Focused Therapy with Children: Harnessing Family Strengths For Systemic Change (New York: The Guilford Press, 1997).

${ }^{10}$ Violence is any form of real human action and behavior that uses force, shows strength or is caused by force, which causes other people to suffer, get hurt, injured, lose a member of the body, and/or even lose their life. Violence can also be shown without real physical behavior, but through harsh words and strong arguments to other parties, causing the other party's feelings to feel harassed, annoyed, humiliated, offended, emotional, and even angry. The first type is called behavioral violence and the second type is called non-physical violence or symbolic violence. See: Darmin Tuwu, Konflik, Kekerasan, dan Perdamaian (Kendari: Literacy Institute, 2018), 84-85.

${ }^{11}$ Aas Saomah, “Permasalahan-Permasalahan Anak dan Upaya Penanganannya,” 2017.

${ }^{12}$ Sunarni Sunarni, Darmin Tuwu, and Ratna Supiyah, "Pelaku Pelecehan Seksual dan Proses Pembinaannya (Studi di Lembaga Pembinaan Khusus Anak Kelas II Kota Kendari),” Jurnal Kesejahteraan dan Pelayanan Sosial 1, no. 1 (2020): 33-47.

${ }^{13}$ Nikmah Rahmawati, "Kenakalan Remaja dan Kedisiplinan: Perspektif Psikologi dan Islam," Sawwa: Jurnal Studi Gender 11, no. 2 (2017): 267-88, https://doi.org/10.21580/sa.v11i2.1458.
} 
until the problem related to the religiosity problem and spiritual coping on the children face to the law. ${ }^{15}$

The problems faced by the child are various according to the condition, the age level, and educational levels, such as Early Childhood Education Programs, Elementary School, and the Adolescent School (Junior High School-Senior High School). The problems dealt with by the early age child of early childhood education programs: wetting the bed, being difficult to eat, being sleepy, the anxiety in a new area, deceiving friends, and the anxiety of being apart from the parents. The problems faced by the children at the age of Elementary School, such as: being lazy to go to school, being difficult to be friends, insulted by friends, learning-difficulty, and being lazy to make dormitory work. The adolescent problems are fighting, mocking friends, telling a lie, making a noise, consuming a lifestyle, being affected by liquor and forbidden drug, smoking, skipping school, free sex, and the addiction to games, social media, and pornography. 16

Children have many problems; they should get attention, guidance, protection, and intervention from the family and the adults in their social environment. So, the children problems can be solved well, so that the children can live adequately, grow and develop well until he becomes mature and grown-up. Among the way of decreasing and overcoming the problems on children, for instance: respecting the children, the implementation of the rules, being an excellent example for the children, giving support to the children, providing time for the children, watching the learning-activity at the orphanage, teaching responsibility, being the best friend, being discipline to keep the children health, listening to the children complain, and so forth.

\section{Social Intervention Method on Children in RTIU-SICA}

Social method intervention on children constitutes the way of handling the problem children, improving or increasing the functioning of children social to take part well according to the children's social individual task. ${ }^{17}$ The method of

\footnotetext{
${ }^{14}$ Khaerul Umam Noer, "Mencegah Tindak Kekerasan pada Anak di Lembaga Pendidikan," Sawwa: Jurnal Studi Gender 14, no. 1 (2019): 47-66, https://doi.org/10.21580/sa.v14i1.2998.

${ }^{15}$ Sukiman Sukiman, Seri Pendidikan Orang Tua: Mendampingi Anak ketika Bermasalah (Jakarta: Kementerian Pendidikan dan Kebudayaan, 2017), 2-5.

16 Sukiman.

${ }^{17}$ Isbandi Rukminto Adi, Kesejahteraan Sosial (Jakarta: RajaGrafindo Persada, 2015), 164.
} 
social intervention given to the children and adolescent uses individual casework method in the form of the transferring of knowledge and skill, in which the process and its phases are as follows: 1) to be initiated with the assessment process towards the real condition of children and adolescents, what the problem is faced, and the potential they have. 2) After knowing the children's problem and potential, the next phase is giving knowledge and skill that in line with the interest and talent owned to accomplish the problem. 3) Accordingly, the transferring of knowledge and skill on children is based on assessing children's problems and needs. ${ }^{18}$

The steps in doing intervention to overcome the problems of children cover the following things. Hogan described the process of sustainable empowerment as a cycle consisting of 5 main phases, namely:191) bringing back the empowering and the non-empowering experiences; 2) discussing the reason why the empowering and the non-empowering happen; 3) identifying a problem or project; 4 ) identifying the base of the expressive power to do the change; and 5) developing the plans of action and implement them.

To solve the problems conceptually uses the approach of Charles Zastrow and Wong that describes the process of counseling through the method of individual casework, in the light of the client, namely: starting from the phase of making aware the existence of problems, the strategy of overcoming the problem, until the evaluation of the activity. ${ }^{20}$

\section{Services of RTIU-SICA of Social Office of Southeast Sulawesi Province}

Regional Technical Implementation Unit of Social Institution of Children and Adolescent cultivates 50 foster children from various regencies and cities in Southeast Sulawesi. Before entering the dormitory, the children and adolescents are selected previously based on the origin; from the result of selection, the children are placed in the dormitory in Social Institutions of Children and Adolescents. As long as the child is in the dormitory, all living costs are underwritten by the government. Besides, the children will also get social services in counseling, education, and facility utilization of infrastructures freely.

\footnotetext{
${ }^{18}$ Adi, 167-70.

${ }^{19}$ Christine Hogan, Facilitating Empowerment: A Handbook for Facilitators, Trainers and Individuals (New York: Unwin Hyman Ltd, 2000).

${ }^{20}$ Zastrow, Empowerment Series: Introduction to Social Work and Social Welfare: Empowering People; Wong, Clinical Case Management for People with Mental Illness: A Biopsychosocial Vulnerability-Stress Model.
} 
Only the child that meets the requirements will be accepted into the orphanage. The child's requirement that may live in the dormitory comes from the low-income family, the problem children in a social manner, the child from the broken orphanage, the skipping school child.

In 2020 RTIU-SICA receives 50 children consisting of 22 boys and 28 girls. Sixteen children consist of 7 boys and nine girls with the level of education of Junior High School, while the adolescent who goes to school at the educational level of Senior High School as many as 34 persons consisting of 15 boys and 19 girls. Several statuses of a child living in the dormitory, namely the one with the status of the poor parents amount to 47 persons, and the child with the status of orphanage, are as many as three persons.

In connection with how the process of selection and requirement of the child received to live in the dormitory every new academic year can listen well from the quotation of an interview with Dormitory handler of this following RTIU SICA.

"Regional Technical Implementation Unit of Social Institution of Children and Adolescent denote the only dormitory that moves in the field of Children and Adolescent by using the selection system. The children are they who have the age of 0-18 years. However, the children who may enter in RTIU SICA are solely the ones between 10 and 18 years. They are given the priority on the children who skip school beginning from the age of the fourth grade of Elementary School to senior high school. They do not stay in the dormitory for the adolescent, but they are solely given skill training from June to September every year. The training ship of skill given to the boy teenage is furniture carpentry (cupboard, table, chair, ventilation, bed, and frame of the window), and girl teenage is in sewing and facial cosmetic skill. The trainer is brought in from the outside who are experts in their every field" (Kulle, interview 2020).

It is still related to the selection and requirements of children and adolescents that will come into the Dormitory of RTIU-SICA and can be paid heed from the quotation of an interview with one of the following Dormitory Guiders of RTIU-SICA.

"All of the children and adolescents that enter in this dormitory through the process of selection, because this dormitory is referred to them who are low, the problem children or susceptible with their family like a parentless, homeless child and so on. Besides recruiting the children, we also recruit the adolescent, but they are only given the training ship of skill for four months every year, namely every June to September. The training ship of skill given for the man in the form of the furniture carpentry and sewing, while for the girls 
teenage, are given sewing and facial skill. The requirements of teenage have not yet been married, and have not yet a job" (Nasdar, interview 2020).

Based on the interview mentioned above, it can be known that not all children and adolescents may enter and then reside in the dormitory, but the children and adolescents require a number of the requirements established by the Dormitory handler. Children's requirements are between 10 and 18 years, the poor children, the problem children, parentless children, homeless children, etc. Whereas the adolescent requirement is the one who has not yet married and has not yet a permanent job but has the potential and talent to be developed. Besides the requirements, the children and adolescents recruited and stated to be received to live in the dormitory must obey all rules and regulations that prevail in the dormitory to continue their education when they live in the dormitory graduate from Senior High School.

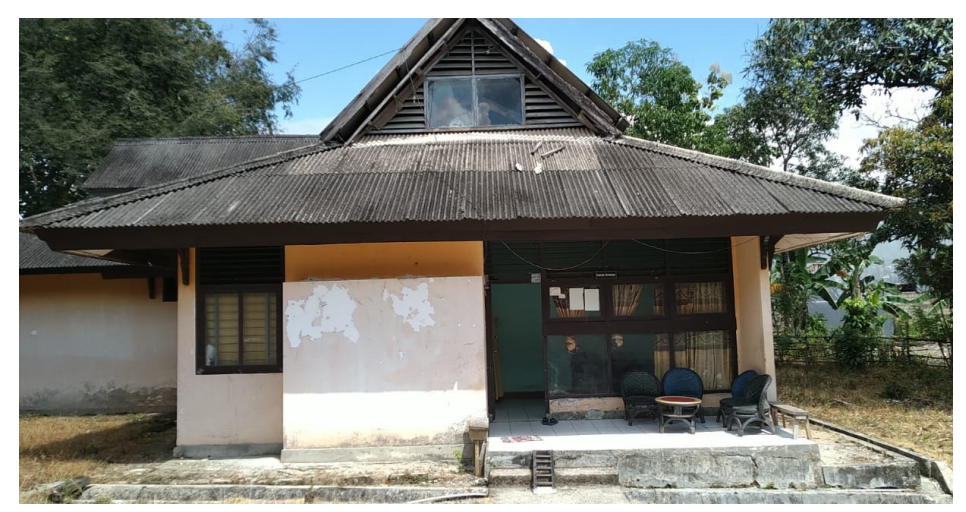

Figure 1.

Cottage of Living-Place for Child of RTIU-SICA (personal documentation, 2020)

Related to how the continuity of child education enters social institutions and adolescents can be paid heed from the interview quotation with one of the following Dormitory handlers of RTIU-SICA.

"We as the handler and guider of dormitory here are responsible for all children in the dormitory. For the children who skip school, after the children pass from selection and are accepted here, our obligation as the handler is to maintain and send the school to the client until they graduate from Senior High School. The dormitory party will handle all files needed by the school like moving-letter, Family Card, certificate of domicile, parents' identity, and 
another file needed by the school. All of the school of the dormitory handler's needs and necessities provides" (Nasdar, interview 2020).

Children and adolescents who pass from the selection enter; they will live in the dormitory and be maintained and guided by the government through the handler of RTIU-SICA. One of the dormitory handlers' obligations is sending the children to school until they graduate from Senior High School. All expenses related to infant education become the liability of the dormitory handler. Likewise, the teenage participants are as long as they are in the dormitory, they will be given any skill according to the interest and talent. The children and adolescents are also given other rights like the free-living place (accommodation), consumption, mental cultivation of spirituality, sport, and a variety of other skills.

The following will be expressed in various social services from the dormitory handler given to the child and adolescent as long as they live in the dormitory.

Firstly, the facility of accommodation. Under observation result in the field is known that every foster child is provided living-place in cottages. There are some cottages in RTIU-SICA. The Dormitory children, both the boys and girls, live in the cottage in the office complex of RTIU-SICA. The girls reside in the individual cottage. It is similar to the boys. Accordingly, the living-place for boys is separated from the one for the girls. Every cottage is under the control of the fosterer and guider. The facility provided on every building is living-room, one set of chairs of living-room, middle room, bedroom equipped with a bed, mattress and pillow, learning-table and wardrobe, the room Dormitory the Guider, kitchen, and two bathrooms.

Secondly, free food and beverage. When living in the dormitory, all food and drink needs and other consumptions entirely become the dormitory handler's responsibility. Every day, the child and adolescent obtain the provision of three times a day, namely breakfast, lunch, and dinner. The menu of food served by the dormitory handler is various and alternating because it is adapted with the condition and taste of children to keep the stamina so that the children remain strong and healthy.

Thirdly, free school. When living in the dormitory, all children are sent to school from Elementary School to Senior High School. All of the school needs such as a book, pen, bag, school uniform, shoes are underwritten by the handler, as well as the school fee is underwritten by the dormitory handler. Besides, every day, the children also still get a transport fee of as much as 10.000 rupiahs per day. 
Fourthly, the cultivation towards the children. The process of cultivation is interpreted in two things, namely mental-spiritual and physical cultivation. Firstly, mental-spiritual cultivation is the process of knowledge transfer, skill, and religious and cultural values. Secondly, physical cultivation makes the children be disciplined towards the norms and rules that prevail in the dormitory. The children can become kind, in order, and discipline. The activity of cultivation is done towards the child primarily when the children violate the Dormitory Handler rules, like when they do not go to school, skip school, and go out of the night without getting permission. The cultivation to the children who break the rule in the form of oral accosting, namely the child, is advised not to repeat their mistakes that are proven with making "statement letter of being guilty." Character-building and mental-spiritual building intensely done by the handler and guider of the dormitory. They taught the lecture and advice of Islamic religious lessons, read the Quran and attend the prayer collectively on time, give motivation so that the children are diligent to study and go to school, the importance of obeying the rules, respecting the elders, liking the youngers, and so on.

Sixthly, besides the children getting an education, residence, consumption, character-building, and mental-spiritual building, children and adolescents are given extra lessons in sports and arts and the Math and English course every week. Through extracurricular activity and English courses, the children can be more intelligent and more independent. It becomes social capital for the child to work when they, later on, live again together with the family and society.

\section{Micro-Intervention Methods for Children with Special Needs in Social Institution of Children and Adolescent of Social Office of Southeast Sulawesi Province}

\section{Children's Conduct who like Mocking friends}

The first problem found in SICA children is liking to bother and bullying roommate or dormitory mate. Bullying friends like this is done in a joking manner. Habit eventually becomes a terrible habit because it can disturb and disturb the children's psychological condition. It is known based on observation $\mathrm{n}$ the field when being in the activity at Mosque or when following the extra lesson material in the English classroom. 
The dormitory guide does not know children's habit of bullying this friend, so the deed of bullying is difficult to stop. The things that become the children's mocking matters; for example, it is about the condition of a bedroom, the measure of children's body, children's race, children's hair, children's conduct, and the problem of the region of origin and tribes.

Related to the children's conduct who likes to disturb and bully his roommate in the Dormitory can be paid heed from the interview with one of the children who like to bother his following friend.

"What is your name? How many years have you lived in the dormitory, and why do you like to disturb your friend? Edi, well sir, I have lived here since a child; my parents come from Konda, South Konawe regency. Because I have lived here, I have already had many friends, sir. We are good friends, including we are in the room. Moreover, I am pleased in this place because I have many friends, it makes me delighted. Some of them are boys; others are girls. There are the friends that I like, but there are also the ones that I dislike. That is why I often disturb him or her, or conversely, he/she also likes to bother me (Husnul, interview 2020).

Based on the interview, it can be known that a child who likes to disturb and mock the roommate due to them, these children have socially known to one another, they have been close to one another, they were like siblings. They were as though elder and younger brothers/sisters in a family, like kidding every day, like to disturb their friends if their will is not met with or is expressing something. For the child who likes to bother and mock friends, bothering or mocking the friend is the expression of the like or dislike of a child or the mental description of a child who likes and dislikes the friend or something.

Even though, it is admitted that the action of bothering and mocking fellow friends is a right thing between fellow friends. If the frequency is done excessively with a continual intensity. The child who is locked to be harmful and destructive because psychologically will disturb the mind and spirit and the child's conduct that becomes the victim of mock. Related to the child's behavior that likes bullying happens when the child is doing an activity together in the activities like sports, cleaning room, and the yard of dormitory (cottage), following the activity in the mosque, following the activity in the classroom, and the like. The condition of playing with friends, kidding one another is shown in the following figure.

Figure 2 shows children in front of the door talking and laughing at the child standing. His friends will undoubtedly hurt the child being talked about 
and laughed at by his friends because he has a different opinion. The disturbing and bullying action will, at last, offend and hurt the feeling of friends both physically and psychologically.

To know how the feeling of a child who is disturbed, mocked, and hurt can be paid heed on the interview with one of the following children of this SICA.

"How do you feel when being disturbed or mocked by your friends? I get annoyed while showing the face of dislike. Frankly, I sometimes feel insulted by my friends living in this dormitory. They said that I am not smart enough, I am not kind, I am not pretty, and so on. Nevertheless, I keep being patient to receive it although in my heart I feel annoyed" (Azizah, interview 2020).

The child's psychological impact is often mocked because the child occasionally tends to be alone and prefers to be quiet to playing jokes and laughing with his friends. Even if the wrong action is not stopped, it will affect the child's psychological and personality development in the future. For instance: the child will tend to behave closed towards the issues that he undergoes, the child will feel ashamed, not be self-reliant, and so forth.

The solution offered is saying to the children of the dormitory primarily the ones who like to disturb and mock their friends so that they will stop the bad conduct, because the conduct is not right, violates the ethics, and is not in keeping with the religious and cultural lesson that we adhere. The fellow human child must affect, respect, and help one another.

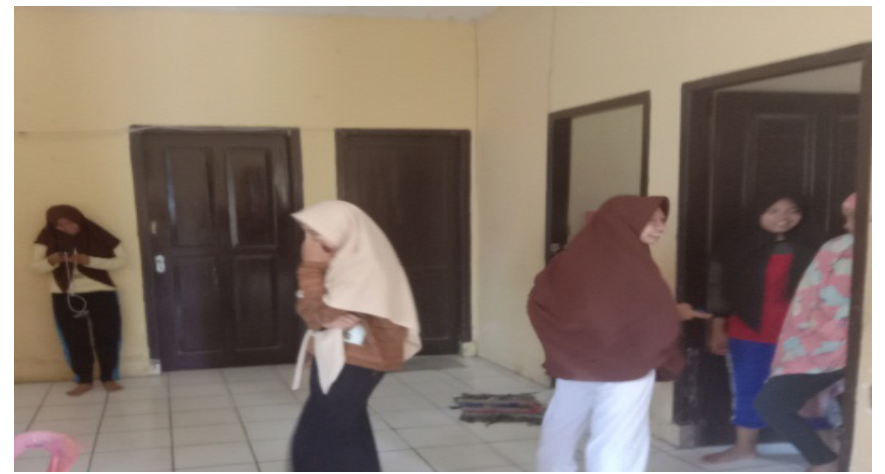

Figure 2.

The condition of playing jokes and kidding of the children when doing an activity (personal documentation, 2020) 


\section{Going out of Night without Permission of the Guider}

All institutions in society (formal and informal institutions) have their own rule that fellow members must obey to create a peaceful and safe life. Likewise, the Governmental Institution of Social Office of Southeast Sulawesi Province named the Social Institution of Children and Adolescent. Among the existing rule in SICA is that every cottage or dormitory resided by several children residing in the roos that have been provided in which a Guider guides every cottage. A Guider of the Dormitory is responsible for the child's survival and success as long the child is in the dormitory. Every cottage has a rule that every child must obey. The rule that must be followed and obeyed by every child, for instance, every child that goes out of the dormitory out of the school schedule (especially if going out at night), must get permission from the fosterer. If it is found a child who goes out of the night without getting permission from the fosterer, it is called to force him/herself and break the rule.

However, in reality, it turned out that all children do not always obey the rule. The fact is found that several children force themselves and are brave to go out of the dormitory at night without getting permission from the fosterer. Based on observation, when spending the night in RTIU of Social Institution of Children and Adolescents of Social Office in Southeast Sulawesi province at 23 o 'clock in Southeastern Time, some boys go out and go in the dormitory. Strangely, the children who go about do not want to admit their conduct. However, children who are neighbors with children who like to go out at night emphasize that children like to go out at night without their guider permission. The following interview shows it.

"Is it true that there is your friend that likes to go out of night without permission from the fosterer? It is true Sir, I frequently see, sometimes several children are going out at night, but I do not know precisely the person, but I am sure that he is the dormitory child that lives here. I occasionally want to accost him/her, but I am not brave" (Aulia, Interview 2020).

Under the interview above, it can be known that it is indeed found that several children like to gout of the night without getting permission from the Guider. It can be understood because the dormitory of SICA is precisely near the Main Road of Mayjend DI Panjaitan, Kendari Town.

The deed of the children who like to go out at night primarily if going out of the dormitory without known by the fosterer is the example of bad conduct that the other friends need not exemplify. The deed of the children who like to 
go out at night without getting permission from the fosterer and without a clear purpose to go is very worrying, because if it happens a bad thing that is not wanted, so the consequence is not only felt by the child but also is felt by the handler of Dormitory of SICA in totality.

For that reason, it is recommended to the child who likes to go out at night to stop his bad habit and change it into a good habit, namely in the evening, the child is not permitted to go out of the Dormitory without getting permission from the guider and without a clear purpose. A kind child, at night, must be used to learn and do the other positive things like reading Quran, doing school tasks, not staying up late, and after that, go to bed so that tomorrow morning, he will not get up late. If the child sleeps rapidly at night, usually the following day, the child will get up quickly to do morning prayer together in the Mosque of the Dormitory.

\section{Solutions for Handling Children with Special Needs}

The solution of handling the problem child based on the Dormitory in RTIU-SICA is as follows: firstly, for handling a child who likes to disturb and mocks his friends, he is accosting and advising the child that the deed of disturbing and mocking his friends is not good. Thus, the action of bullying must be stopped because psychologically is not suitable for the friend mocked.

Secondly, for the child who likes to go out at night without getting permission from the dormitory's fosterer is terrible action. Accordingly, a good child should not go out at night. The time of night should be used for the festive activities discussing in groups.

Thirdly, to develop a sense of self-reliance and a child's bravery, the guided child is given extra lessons out of the school schedule. Providing the extra lesson like in the religious field can study to read the Quran, memorize the Quran, give a lecture, in the field of sport, can do self-defense like Karate, playing football, playing craw, taking English and Math Course. The mastery towards this extra lesson is expected as one to be able to make the guided child high motivation and spirit. Thus, the guided child of the dormitory can make work and achieve at school and in society.

Fourthly, there needs to be a harmonious interaction and more intensive communication between the guided child and the guide to creating a close relationship. Creating a close inner situation between the guided child and the 
guide makes the condition flexible and makes the child happy. Suppose the child and parents' closeness has been created. In that case, when the child is given motivation, he will be readily accepted, and the positive impact is that when the child usually is easily arranged, guided, and bred. Sometimes, the child is taken to go for a stroll to the entertainment places or tourist places so that the child is happy and is not stressed with the daily routine in the dormitory.

Eventually, the methods of handling children based on dormitory used so far are that physical and mental-spiritual building that has not yet been effective makes the child disciplined and in good order. The child's boredom causes it because the one giving material comes from the handler party. This research showed that the child needs a new atmosphere and trainer to increase the motivation and creativity. Therefore, collaboration with another party like the university is broadly expected to accelerate the child's spirit and creativity.

\section{E. Conclusion}

The micro intervention method on the problem children based on the dormitory aims to give the children knowledge, skill, and religious and cultural values to become a kid child and overcome their problems. Likely to insult and mock friends, skipping school, lazy to study, dishonest, less discipline, telling a lie, going out of the night without getting permission from the guider. Method of child handling that undergoes the social institution i.e: firstly, method of mentalspiritual building. This method is given to the child in lecture and religiosity study, to mental attitude and lofty behavior. Secondly, physical method. This method is explicitly given to the child who breaks the Dormitory rule, such as; liking to mock friends, skipping school, liking to go out of the night without getting permission from the guide, and the like. It is different from the building of the new order era that still adopts the strict military way; child building in the reformation era features more soft ways to avoid violence. If there is any child who breaks the rule, the guide solely gives oral accost and the advice of kindness so that the child does not repeat the wrong action. Thirdly, method of transferring extra lesson to the child. This method is more suitable to be given to the child so that the child has business to do sport, learn English, and a variety of other festive activities. However, unfortunately, almost all sports infrastructures in the dormitory are currently in bad condition, so that child's positive activity is not sustainable. Fourthly, micro intervention to the problem child at RTIU-SICA is the effort, commitment, obligation, and responsibility of 
the country, government, university, society, family, and parents to realize the implementation of integrated child protection create social welfare in the future.

\section{Acknowledgments}

The article is part of the internal basic research activity result of Halu Oleo University Kendari in 2020 entitled "Model of Handling on the Problem Child in the Perspective of Social Welfare in RTIU-SICA of Social Office in Southeast Sulawesi Province. The research is supported by the Research and Dedication Directorate to the Society, Research, Technology, and High Education Ministry of Republic of Indonesia and Institution of Research and Dedication to the Society of Halu Oleo University (LPPM-UHO). The activity of research takes place in RTIU-SICA of Social Office in Southeast Sulawesi Province. The authors express thanks a lot to all parties that have contributed so that this research is done. For the help and collaboration is said to thanks.[s]

\section{References}

Adi, Isbandi Rukminto. Kesejahteraan Sosial. Jakarta: RajaGrafindo Persada, 2015.

Fahrudin, Adi. Perspektif Biopsikososial untuk Asesmen Keberfungsian Sosial. Bandung: Refika Aditama, 2018.

Hogan, Christine. Facilitating Empowerment: A Handbook for Facilitators, Trainers and Individuals. New York: Unwin Hyman Ltd, 2000.

Jannah, Hanani Firdhotul, Bahtiar Bahtiar, and Sarpin Sarpin. "Program Pemberdayaan Anak Kurang Mampu pada Panti Sosial (Studi di UPTD Panti Sosial Anak dan Remaja Dinas Sosial Provinsi Sulawesi Tenggara)." Welvaart: Jurnal Ilmu Kesejahteraan Sosial 1, no. 2 (2020): 132-45.

Lesmana, Jeanette Murad. Dasar-Dasar Konseling. Jakarta: UI Press, 2011.

Noer, Khaerul Umam. "Mencegah Tindak Kekerasan pada Anak di Lembaga Pendidikan." Sawwa: Jurnal Studi Gender 14, no. 1 (2019): 47-66. https://doi.org/ 10.21580/sa.v14i1.2998.

Rahmawati, Nikmah. "Kenakalan Remaja dan Kedisiplinan: Perspektif Psikologi dan Islam." Sawwa: Jurnal Studi Gender 11, no. 2 (2017): 267-88. https://doi.org/ 10.21580/sa.v11i2.1458.

Saomah, Aas. “Permasalahan-Permasalahan Anak dan Upaya Penanganannya,” 2017. 
Selekman, Matthew D. Solution-Focused Therapy With Children: Harnessing Family Strengths For Systemic Change. New York: The Guilford Press, 1997.

Siporin, M. Introduction to Social Work Practice. New York: MacMillan, 1975.

Sukiman, Sukiman. Seri Pendidikan Orang Tua: Mendampingi Anak ketika Bermasalah. Jakarta: Kementerian Pendidikan dan Kebudayaan, 2017.

Sunarni, Sunarni, Darmin Tuwu, and Ratna Supiyah. "Pelaku Pelecehan Seksual dan Proses Pembinaannya (Studi di Lembaga Pembinaan Khusus Anak Kelas II Kota Kendari)." Jurnal Kesejahteraan Dan Pelayanan Sosial 1, no. 1 (2020): 33-47.

Tuwu, Darmin. Konflik, Kekerasan, Dan Perdamaian. Kendari: Literacy Institute, 2018.

Tuwu, Darmin, Bahtiar Bahtiar, Ratna Supiyah, and Ambo Upe. "Pemberian Dukungan Psikososial pada Anak yang Mengalami Gangguan di Era Pandemi COVID-19." Journal Publicuho 3, no. 3 (2020): 394-404. https://doi.org/10.35817/ jpu.v3i3.14489.

Wong, Daniel Fu Keung. Clinical Case Management for People with Mental Illness: A Biopsychosocial Vulnerability-Stress Model. London: Routledge, 2006.

Zastrow, Charles. Empowerment Series: Introduction to Social Work and Social Welfare: Empowering People. Boston, MA: Cengage Learning, 2016. 